\section{The Boy Electrician}

Practical Plans for Electrical Apparatus for Work and Play, with an Explanation of the Principles of Everyday Electricity. By Alfred P. Morgan. Fifth edition, revised by J. W. Sims. Pp. $328+11$ plates. (London, Bombay and Sydney : George G. Harrap and Co., Ltd., 1941.) 6s. net.

$\mathrm{N}$ some quarters the die-hard tradition still lives fully up to its namè and in that austere domain this volume would, no doubt, be classed and discussed as just "another of those popular books for the scientifically immature and curious". Such a label, however, would betray nothing but a complete lack of understanding of the times and of sympathy with the aspirations of adolescence. The present book is, in its way, as important to those to whom it is addressed as is many an advanced work to the established scientific or technological worker-maybe even more so in its possible influence in the formative years of youth; because of this we are glad to see the new edition.

The scope of the work is wide and, in parts, a little beyond the capabilities of the average boy experimenter who, for example, will have to advance quite a considerable way with serious studies before he understands the chapters on transmission and on A.c. circuits. No harm is done, however, by introducing these subjects, for they are subordinated to the main issue.

More particularly, the book covers magnets and magnetism, static electricity and machines, cells and batteries, electromagnetism, measuring instruments, telegraphs and telephones, induction coils, electric transmission, transformers, A.c. generators and motors, radio, electric railways, lighting, A.c. circuits, and gas-discharge tubes. The experiments and apparatus devised are such as any boy can carry out and make for himself.

The book is one of a series planned for boys with a craving for investigation, and it serves its purpose well.

\section{S. A. S.}

\section{An Outline of Metallurgical Practice}

By Prof. Carle R. Hayward. Second edition. Pp. $\mathrm{xi}+690$. (London: Chapman and Hall, Ltd., 1941.) 38 s. net.

$\mathrm{T}$ HIS work is intended to serve as a reference book for engineers and also to assist students who are approaching the study of metals without previous practical experience. The first object is excellently fulfilled, it being understood that the term metallurgy is used in a restricted sense, to cover only processes of extraction and refining, and that it is almost entirely confined to American practice, although statistical tables of world production are ineluded. Some previous knowledge is required of the reader, as many of the terms are not defined, and the 400 illustrations are not all self-explanatory. Thus there are several references to the Cottrell treater for dusts, but the fact that this is an electrostatic device is not mentioned. The most valuable feature is the descrip- tion, under each metal in succession, of typical plants and processes, with drawings and photographs. Unlike many text-books covering similar ground, some of which have passed through many editions, the book is not burdened with accounts of obsolete processes.

Here and there, as in the section on magnesium, the lack of reference to European practice involves the omission of processes which are being used successfully, but on the whole the information is full and recent. In dealing with alloys and some smelting processes equilibrium diagrams and photomicrographs are given, without reference to them in the text, but their inclusion is stated to be deliberãte, and to be intended for students who have already followed a course in metallography. As no part of the discussion is based on them, the technical reader without such knowledge is not confused.

Each chapter concludes with a table of the principal properties of the pure metal, and where these have been checked they have been found aceurate, although it is not enough at the present day to record hardness only on the Mohs scale. The book is well produced, but the large type employed makes it rather bulky.

C. H. D.

\section{The Fauna of British India}

Including the Remainder of the Oriental Region. (Published under the patronage of the Secretary of State for India in Council.) Edited by Lt.-Col. R. B. S. Sewell. Diptera. Vol. 6: Family Calliphoridæ. By R. Senior White, Daphne Aubertin and Dr. John Smart. Pp. xiii +288 . (London : Taylor and Francis, Ltd., 1940.) $18 s$.

$\mathrm{T}$ HIS latest addition to "The Fauna of British India" series deals with a group of considerable economic importance, since it comprises those creatures known as 'blow-flies'. At the same time it is concerned with a group greatly needing thorough study. The authors regard the Calliphoridæ as forming a family separate from the Tachinidæ, to which they are closely related. They deal very fully with the external morphology of its members and include in the account a useful illustrated description of the male genitalia, which are of pre-eminent importance for the separation of the different species. While the primary object of their work is taxonomic, the authors give indications regarding the biology of the various species wherever anything at all is known on the subject. Notwithstanding the unpleasant habits of most of their members, the Calliphoridæ are a group of very definite biological interest owing to the diversity of larval and adult habits and the great range of coloration displayed by the flies.

We can recommend this volume as an admirable introduction to the study of the Calliphorids not only of India but of other tropical lands also. The fact that it only deals with what must be a very small proportion of the fauna of these insects will, it is hoped, induce resident Indian entomologists to collect and observe them with more interest than has been shown in the past.
A. D. I. 